\title{
Bcr-Abl-mediated resistance to apoptosis is independent of constant tyrosine-kinase activity
}

\author{
AEB Bueno-da-Silva ${ }^{1,2}$, G Brumatti ${ }^{1,2}$, FO Russo ${ }^{1,2,3}$, \\ DR Green ${ }^{1,3}$ and GP Amarante-Mendes ${ }^{\star, 1,2,3}$ \\ 1 Department of Immunology, Institute of Biomedical Sciences, University of São \\ Paulo, Brazil \\ 2 Institute for Investigation in Immunology, Millennium Institute, Brazil \\ ${ }^{3}$ La Jolla Institute for Allergy and Immunology, San Diego, CA, USA \\ * Corresponding author: GP Amarante-Mendes, Departamento de Imunologia, \\ Instituto de Ciências Biomédicas, Universidade de São Paulo, Av. Prof. Lineu \\ Prestes, 1730 - Cidade Universitária, São Paulo, SP - 05508-900 - Brazil. \\ Tel.: +55 113091 7362; Fax: +55 113091 7224; E-mail: gpam@usp.br
}

Received 22.7.02; revised 3.12.02; accepted 6.12.02

Edited by SJ Martin

\section{Abstract}

Bcr-Abl is one of the most potent antiapoptotic molecules and is the tyrosine-kinase implicated in Philadelphia (Ph) chromosome-positive leukemia. It is still obscure how BcrAbl provides the leukemic cell a strong resistance to chemotherapeutic drugs. A rational drug development produced a specific inhibitor of the catalytic activity of BcrAbl called STI571. This drug was shown to eliminate Bcr-Ablpositive cells both in vitro and in vivo, although resistant cells may appear in culture and relapse occurs in some patients. In the study described here, Bcr-Abl-positive cells treated with tyrosine-kinase inhibitors such as herbimycin A, genistein or STI571 lost their phosphotyrosine-containing proteins, but were still extremely resistant to apoptosis. Therefore, in the absence of tyrosine-kinase activity, Bcr-Abl-positive cells continue to signal biochemically to prevent apoptosis induced by chemotherapeutic drugs. We propose that secondary antiapoptotic signals are entirely responsible for the resistance of Bcr-Abl-positive cells. Precise determination of such signals and rational drug development against them should improve the means to combat $\mathrm{Ph}$ chromosomepositive leukemia.

Cell Death and Differentiation (2003) 10, 592-598. doi:10.1038/ sj.cdd. 4401210

Keywords: apoptosis; Bcr-Abl; leukemia; tyrosine-kinase; STI571

\footnotetext{
Abbreviations: ALL, acute lymphocytic leukemia; CHX, cycloheximide; CML, chronic myelogenous leukemia; FCS, fetal calf serum; mAb, monoclonal antibody; pAb, polyclonal antibody; $\mathrm{pY}$, phosphotyrosine; STS, staurosporine; VP16, etoposide; VM26, teniposide.
}

\section{Introduction}

Apoptosis is a genetically controlled form of cell death that plays a fundamental role during the development and in tissue homeostasis in multicellular organisms. ${ }^{1}$ During tumorigenesis, the expansion of a transformed cell population is directly related to the difference of the rates of proliferation and cell death presented by these cells. ${ }^{2}$ Therefore, interference with the apoptotic machinery resulting in increased survival ability of a certain cell population contributes to the malignant phenotype found in some forms of cancer. This seems to be the case of the Philadelphia $(\mathrm{Ph})$ chromosome-positive leukemia.

Over $95 \%$ of cases of chronic myelogenous leukemia (CML) and 15-35\% of acute lymphocytic leukemia (ALL) are associated with the $\mathrm{Ph}$ chromosome, the outcome of a reciprocal translocation between chromosomes 9 and 22, which generates the chimeric Bcr-Abl molecule with intrinsic tyrosine-kinase activity and altered subcellular compartmentalization. ${ }^{3}$ Bcr-Abl molecules exist in two major isoforms: a $210-\mathrm{kDa}$ protein detected in $\mathrm{CML}$ and a $185-\mathrm{kDa}$ fusion protein in ALL. In addition, a more rare protein of $230 \mathrm{kDa}$ is associated with some forms of chronic neutrophilic leukemia (CNL). In every case, Bcr-Abl has been implicated in cellular transformation and inhibition of apoptosis. ${ }^{4-6}$

Transformation by Bcr-Abl requires its tyrosine-kinase activity $^{7,8}$ as well as the action of the multiple functional domains presented in this molecule to couple downstream signal transduction pathways. ${ }^{5,9-13}$

Many molecular targets have been described to account, at least in part, for the resistance to apoptosis found in Bcr-Ablpositive cells. We have found that Bcr-Abl induces the expression of the antiapoptotic protein $\mathrm{Bcl}-\mathrm{x}_{\mathrm{L}}$, and that downregulation of $\mathrm{Bcl}-\mathrm{x}_{\mathrm{L}}$ by antisense oligonucleotides partially sensitize Bcr-Abl-positive cells to apoptosis. ${ }^{14}$ Later, it was shown that Bcr-Abl activates the transcription of $b c l-x_{L}$ through the activation of Stat5..$^{15-17}$ The PI3K/Akt pathway was also suggested to participate in the Bcr-Abl-mediated resistance to apoptosis, ${ }^{18,19}$ although it is important to mention that in our experimental system, using HL-60 cells transfected with $\mathrm{p} 185^{b c r-a b l}$, the strong antiapoptotic signal is clearly independent of $\mathrm{PI} 3 \mathrm{~K}$ activity. ${ }^{20}$ Another molecule potentially involved in the apoptosis protection found in BcrAbl-positive cells is the transcription factor NF- $\kappa \mathrm{B}$, which is implicated in the induction of endogenous caspase inhibitors of the IAP family ${ }^{21}$ and was shown to be required by Bcr-Ablmediated transformation. ${ }^{22,23}$

Although many more work has been published on Bcr-Ablmediated signaling cascades, we still know very little about how this molecule interferes with the apoptotic machinery. In particular, it is not known whether Bcr-Abl tyrosine-kinase is required to be constantly active in order to maintain the resistance to apoptosis observed in Bcr-Abl-expressing cells. Therefore, in the present study, we use tyrosine-kinase 
inhibitors to address whether the presence of phosphotyrosine (pY)-containing proteins is necessary to prevent apoptosis induced by a variety of apoptogenic insults.

\section{Results}

\section{Broad-spectrum inhibitors of tyrosine-kinases block phosphotyrosine-containing proteins but not the resistance to apoptosis of HL-60.Bcr-AbI cells}

To investigate the role of pY-containing proteins in Bcr-Ablmediated resistance to apoptosis, we treated HL-60 and HL60.Bcr-Abl cells with two broad-spectrum tyrosine-kinase inhibitors, namely herbimycin $A$ and genistein. Both drugs were able to inhibit the appearance of $\mathrm{pY}$-containing proteins in a dose-dependent manner, as assessed by Western blots using anti-pY antibodies. Herbimycin A was most efficient at $100 \mathrm{ng} / \mathrm{ml}$ (Figure 1a), whereas genistein was capable to significantly reduce the levels of $\mathrm{pY}$-containing proteins at $250 \mu \mathrm{g} / \mathrm{ml}$ (Figure 2a). Incubation for $24 \mathrm{~h}$ with either herbimycin $\mathrm{A}$ or genistein alone did not induce cell death in both HL-60 and HL-60.Bcr-Abl cells (Figures $1 \mathrm{~b}$ and $2 \mathrm{~b}$, left panels). Interestingly, even in the presence of $100 \mathrm{ng} / \mathrm{ml}$ herbimycin A (Figure 1b, center and right panels) or $250 \mu \mathrm{g} / \mathrm{ml}$ genistein (Figure 2b, center and right panels), HL-60.Bcr-Abl cells were extremely resistant to apoptosis induced by $100 \mu \mathrm{M}$ $\mathrm{CHX}$ or $50 \mu \mathrm{M}$ VP16.
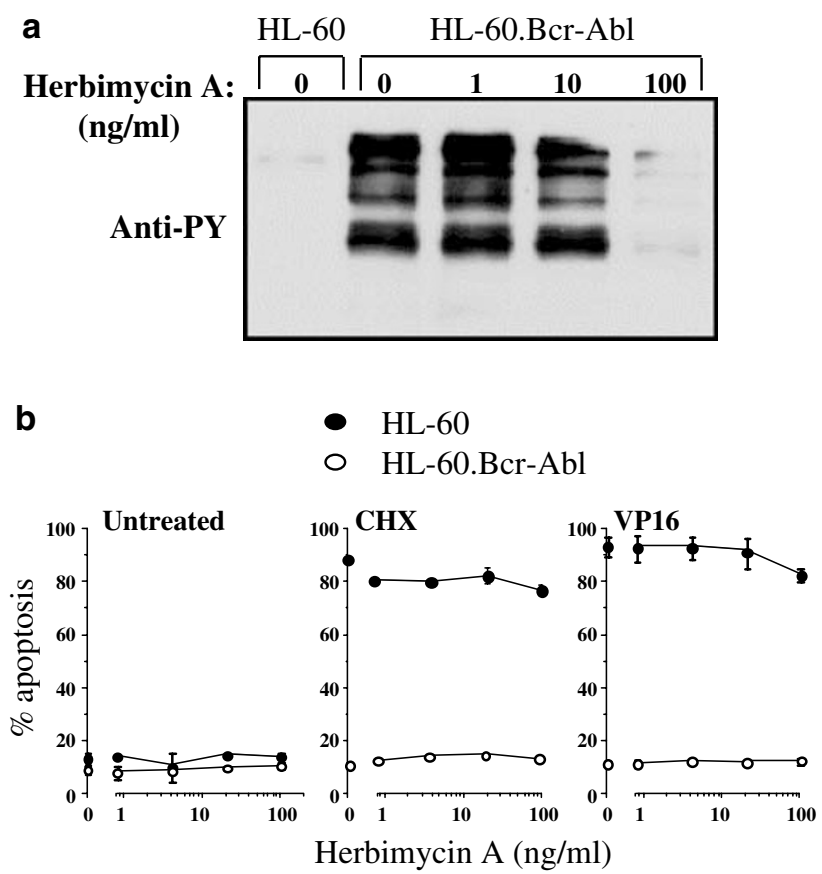

Figure 1 Herbimycin $\mathrm{A}$ inhibits $\mathrm{pY}$-containing proteins but does not interfere with the resistance of $\mathrm{HL}-60 . \mathrm{Bcr}-\mathrm{Abl}$ cells. $\mathrm{HL}-60$ and $\mathrm{HL}-60 . \mathrm{Bcr}-\mathrm{Abl}$ cells were pretreated for $1 \mathrm{~h}$ with different concentration of herbimycin $A$ (a) and subsequently incubated overnight in the presence of $100 \mu \mathrm{M} \mathrm{CHX}$ or $50 \mu \mathrm{M}$ VP-16 (b). Percentage of cell death was estimated by the analysis of DNA content, as described in Materials and Methods. These results are from a representative of two different experiments done in triplicates

\section{Bcr-Abl-mediated resistance to apoptosis is preserved in HL-60 cells treated with STI571}

Since HL-60.Bcr-Abl cells were still resistant to apoptosis in situations where the level of $\mathrm{pY}$-containing proteins dropped substantially, we decided to broaden our investigation and test whether a specific Bcr-Abl tyrosine-kinase inhibitor would provide different results than herbimycin $A$ and genistein. STI571 is a very potent Bcr-Abl kinase inhibitor that has been used with great success in clinical trials to treat $\mathrm{Ph}$ chromosome-positive leukemia (reviewed in Mauro and Druker $^{24}$ ). In addition, it has been shown that cell lines derived from $\mathrm{Ph}$ chromosome-positive leukemia patients die upon treatment for a few days with STI571. ${ }^{25,26}$

We therefore incubated HL-60 and HL60.Bcr-Abl cells with $10 \mu \mathrm{M}$ STI571 and inspected the levels of Bcr-Abl and pYcontaining proteins after 2 and $24 \mathrm{~h}$. As we can see in Figure 3 , $\mathrm{HL}-60$ cells are very meager in pY-containing proteins. In contrast, HL-60.Bcr-Abl exhibited a great amount of these molecules, which disappeared after $2 \mathrm{~h}$ in the presence of STI571 and remained almost undetectable at least for the following $22 \mathrm{~h}$. With these results in mind, we pretreated HL60 and HL60.Bcr-Abl cells with STI571 for $2 \mathrm{~h}$ and then incubated each of them in the presence or absence of VM26, VP16, CHX or STS for $22 \mathrm{~h}$. At the end of the assay, we evaluated the level of apoptosis in each experimental situation by quantify phosphatidylserine externalization. Although the STI571 blocked the Bcr-Abl tyrosine-kinase activity, and the consequent appearance of $\mathrm{pY}$-containing proteins, prior to apoptogenic drug administration, it did not interfere with the resistance to apoptosis of HL-60.Bcr-Abl for the following $22 \mathrm{~h}$ (Figure 4).

a

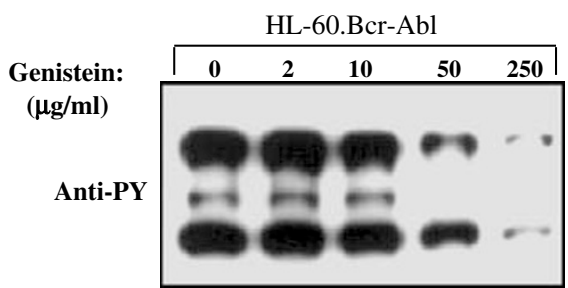

b

- HL-60

○ HL-60.Bcr-Abl

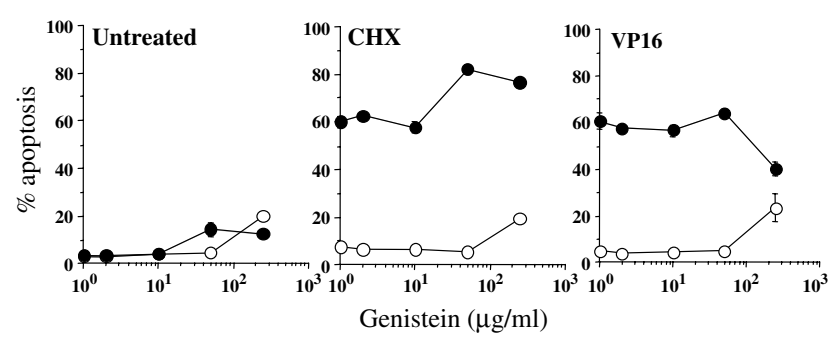

Figure 2 Genistein inhibits $\mathrm{pY}$-containing proteins but does not interfere with the resistance of $\mathrm{HL}-60 . \mathrm{Bcr}-\mathrm{Abl}$ cells. $\mathrm{HL}-60$ and $\mathrm{HL}-60 . \mathrm{Bcr}-\mathrm{Abl}$ cells were pretreated for $45 \mathrm{~min}$ with different concentration of genistein (a) and subsequently incubated overnight in the presence of $100 \mu \mathrm{M} \mathrm{CHX}$ or $50 \mu \mathrm{M}$ VP16 (b). Percentage of cell death was estimated by the analysis of DNA content, as described in Materials and Methods. These results are from a representative of two different experiments done in triplicates 


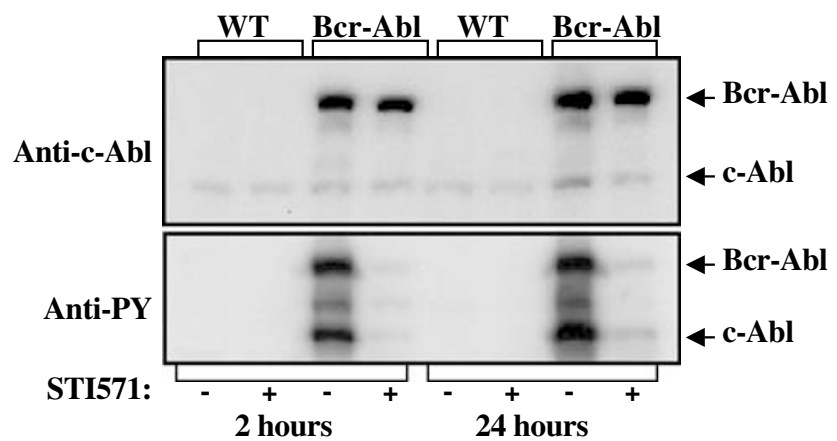

Figure 3 The Bcr-Abl tyrosine-kinase inhibitor STI571 suppresses pYcontaining proteins in $\mathrm{HL}-60$. Bcr-Abl cells without interfering with Bcr-Abl levels. $\mathrm{HL}-60$ and HL-60.Bcr-Abl cells were treated with $10 \mu \mathrm{M}$ STI571 and samples were prepared for Western-blot analysis as described in Materials and Methods, after 2 and $24 \mathrm{~h}$.

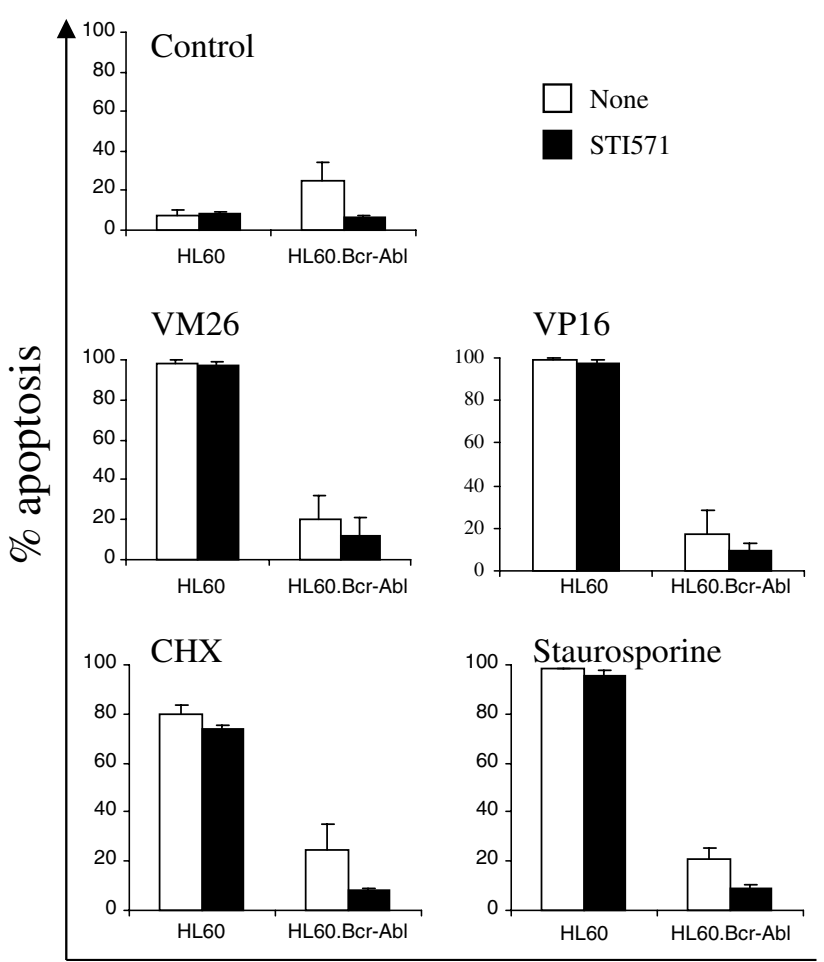

Figure 4 STI571 does not sensitize HL-60.Bcr-Abl cells to apoptosis. HL-60 and $\mathrm{HL}-60 . \mathrm{Bcr}-\mathrm{Abl}$ cells were treated for $2 \mathrm{~h}$ with $10 \mu \mathrm{M} \mathrm{STI571}$ and then incubated for another $22 \mathrm{~h}$ in the presence or absence of VM26 $(10 \mu \mathrm{M})$, VP16 $(50 \mu \mathrm{M}), \mathrm{CHX}(50 \mu \mathrm{M})$ or STS $(1 \mu \mathrm{M})$. STI571 remained in the culture for the duration of the experiment. The level of apoptosis was quantified by the analysis of phosphatidylserine externalization. These results are representative of three independent experiments done in triplicates

\section{STI571 does not sensitize Bcr-Abl-positive cells to caspase activation following chemotherapeutic drugs}

It is well known that the apoptosis program is executed by members of the caspase family of proteases, in particular caspase-3. Therefore, we investigated whether caspase-3 could be activated in Bcr-Abl-positive cells by chemotherapeutic drugs in the presence of STI571. Figure 5 shows the

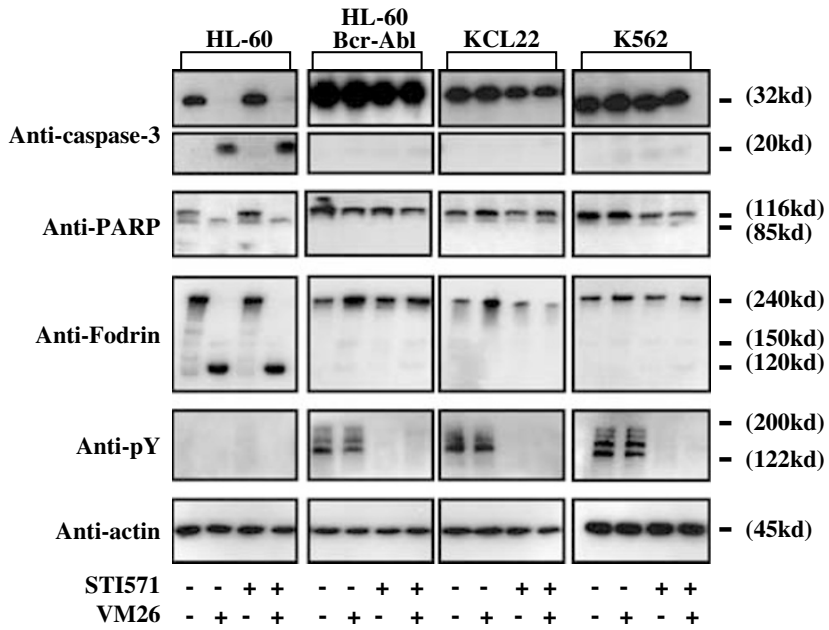

Figure 5 STI571 does not sensitize Bcr-Abl-positive cells to caspase activation following chemotherapeutic drugs. Cells were treated or not for $2 \mathrm{~h}$ with $10 \mu \mathrm{M}$ STI571 and then incubated for another $22 \mathrm{~h}$ in the presence or absence of VM26 $(10 \mu \mathrm{M})$. STI571 remained in the culture for the duration of the experiment. Western-blot analysis was performed as described in Materials and Methods

Western-blot analysis of caspase-3 activation and cleavage of two apoptotic substrates. As expected, VM26 induced both caspase-3 activation and cleavage of PARP and fodrin in $\mathrm{HL}$ 60 cells, but not in the Bcr-Abl-positive cell lines. In accordance to our results mentioned above, STI571 alone was not able to induce either caspase-3 activation or the cleavage of PARP or fodrin associated with apoptosis, in all of the Bcr-Abl-positive cells tested. Although STI571 blocked Bcr-Abl tyrosine-kinase activity and the associated appearance of pY-containing proteins in HL-60.Bcr-Abl, KCL22 and K562 cells, as revealed by the anti-pY blots, STI571 did not sensitize these Bcr-Abl-positive cells for caspase-3 activation after VM26. Moreover, these results were corroborated by the analysis of DNA fragmentation of five different Bcr-Ablpositive cell lines incubated with VM26 (Figure 6) or Act-D, CHX or STS (not shown). In every case tested, Bcr-Ablpositive cells maintained their resistance to apoptosis in the presence of STI571.

\section{Resistance to apoptosis in the presence of STI571 does not involve $\mathrm{Bcl}-2$ or $\mathrm{Bcl}-\mathrm{x}_{\mathrm{L}}$}

We have previously shown that part of the antiapoptotic effect of the expression of Bcr-Abl in HL-60 cells was because of an upregulation of $\mathrm{Bcl}-\mathrm{x}_{\mathrm{L}}{ }^{14}$ Therefore, in order to gain insight about the mechanism by which Bcr-Abl-positive cells remain resistant to apoptosis in the absence of Bcr-Abl tyrosinekinase activity, we decided to look at the levels of $B c l-x_{L}$ after incubation with STI571. As shown in Figure 7, the disappearance of $\mathrm{pY}$-containing proteins observed in the presence of STI571 was correlated with a reduction of the levels of Bcl$\mathrm{x}_{\mathrm{L}}$ in all three different Bcr-Abl-positive cells, namely HL60.Bcr-Abl, K562 and LAMA84. Bcr-Abl-positive cells were all devoid of detectable $\mathrm{Bcl}-2$ protein in the presence or absence of STI571 (Figure 7). 


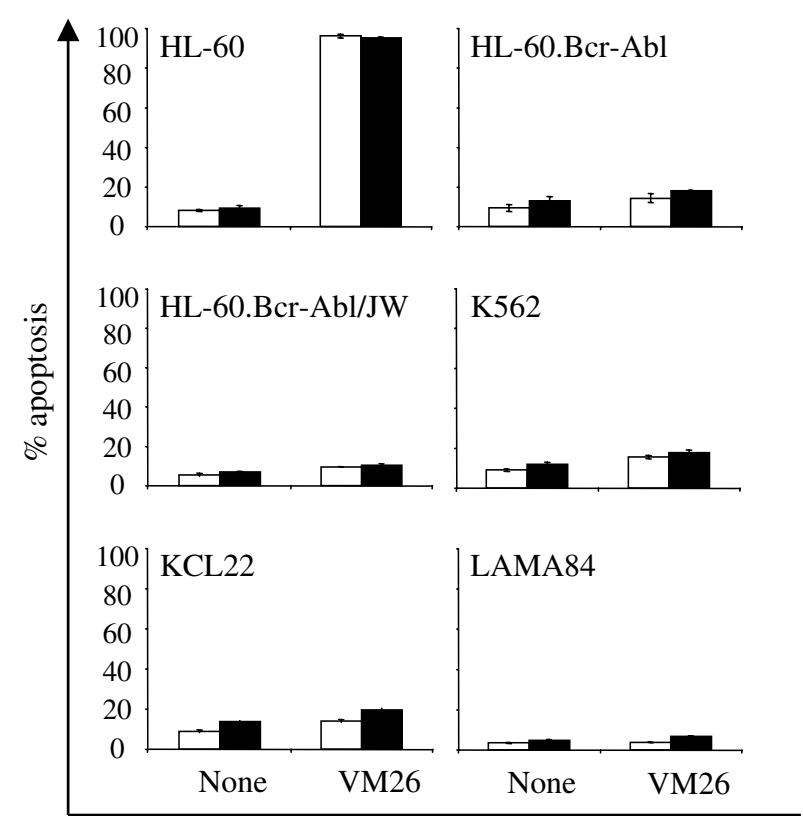

Figure 6 Resistance to apoptosis in Bcr-Abl-positive leukemia lines is not prevented by STI571. Cells were treated (closed bars) or not (open bars) for $2 \mathrm{~h}$ with $10 \mu \mathrm{M} \mathrm{STI571}$ and then incubated for another $16-22 \mathrm{~h}$ in the presence or absence of VM26 $(10 \mu \mathrm{M})$. STI571 remained in the culture for the duration of the experiment. The level of apoptosis was estimated by the analysis of DNA content, as described in Materials and Methods. These results are from a representative of three different experiments done in triplicates

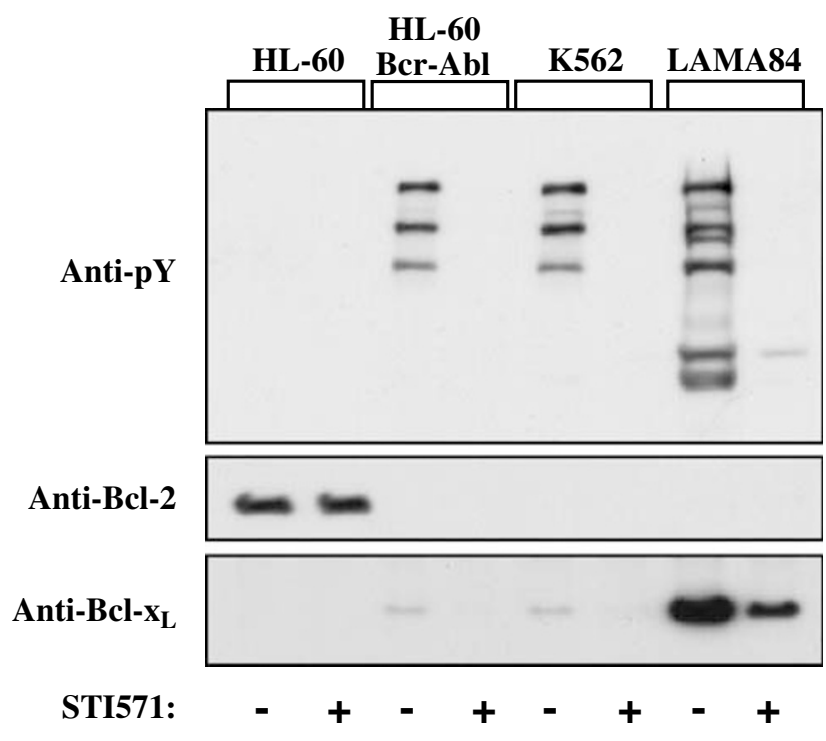

Figure 7 Treatment with STI571 inhibits the expression of Bcl- $\mathrm{x}_{\llcorner}$. Cells were treated or not for $16 \mathrm{~h}$ with $10 \mu \mathrm{M} \mathrm{STI571}$ and then prepared for Western-blot analysis as described in Materials and Methods

\section{Discussion}

Since the tyrosine-kinase activity of the Bcr-Abl molecule was shown to be necessary for the transforming ability of this oncogenic molecule, ${ }^{7,8,10}$ it was expected that pharmacological intervention with its catalytic domain would produce a beneficial clinical effect for Ph chromosome-positive patients. In fact, as a result of rational drug development, STI571, a 2phenylamino pyrimidine that interfere with the ATP-binding site of the Abl kinases, ${ }^{26}$ has emerged as a very efficient drug against Bcr-Abl-positive leukemia. ${ }^{24,27,28}$

Although CML patients at the chronic phase of the disease responded in general well and persistently to the drug, blast crisis patients often relapse even if the STI571 treatment is continued. ${ }^{29}$ Part of the reason that the disease relapses in some patients seems to be due to a progressive $b c r-a b l$ gene amplification or to a single aminoacid substitution in the ATP-binding pocket of the Abl kinase domain, critical to the interaction with the STI571. ${ }^{30-33}$ Moreover, in at least one case, the resistance of Bcr-Ablpositive cells to STI571 appears to be associated with an increased expression of the multidrug-resistance P-glycoprotein (Pgp). ${ }^{31}$ Lastly, some STI571-resistant cell lines generated in vitro presented no bcr-abl gene amplification or mutation and no Pgp upregulation, therefore raising the possibility that compensatory alterations in other survival genes might account for the resistance to STI571. ${ }^{31}$

Here, we found out that Bcr-Abl-positive cells, despite responding to herbimycin A, genistein and STI571 with a blockage of Bcr-Abl kinase activity and consequent disappearance of $\mathrm{pY}$-containing proteins, remain extremely resistant to apoptogenic insults under these circumstances. Our data suggest that $\mathrm{pY}$-containing proteins may not be responsible for the antiapoptotic effect of Bcr-Abl. However, it is important to mention that subdetectable amount of tyrosine-phosphorylated Bcr-Abl targets may exist and could be still effective in protecting cells from apoptosis. Alternatively, such $\mathrm{pY}$-containing proteins may participate only earlier in the transduction of downstream antiapoptotic signaling events that can be active for a short period of time in the absence of both Bcr-Abl kinase activity and tyrosine-phosphorylated proteins. Thus, secondary antiapoptotic signals initiated by the activity of the Bcr-Abl tyrosine-kinase might entirely account for the resistance to chemotherapeutic drugs observed in Bcr-Abl-positive cells. The identification of such survival signals will definitely help to understand the nature of the Bcr-Abl-mediated resistance to apoptosis, and to design new strategies for the treatment of Ph chromosome-positive leukemia.

It is important to mention that, in a long term, these antiapoptotic signals probably need a restimulation by the BcrAbl tyrosine-kinase, since all of our Bcr-Abl-positive cells lines displayed a high frequency of cell death after 2-4 days in the presence of high doses of STI571 (Bueno-da-Silva, AEB and Amarante-Mendes, GP, unpublished observations). These results are similar to the earlier findings in the literature showing that treatment with STI571 induces a time-dependent apoptosis in a variety of Bcr-Abl-positive cells. ${ }^{25,26,34}$ Interestingly enough, it was demonstrated that STI571 sensitizes HL-60.Bcr-Abl cells to apoptosis induced by Ara$\mathrm{C}$ or doxorubicin. ${ }^{35}$ Although in seeming contradiction to our own observation, Fang and collaborators treated HL-60.BcrAbl cells with a much lower dose of STI571 (0.25 $\mu \mathrm{M})$ and for a longer period of time $(48 \mathrm{~h})$. It is conceivable that the downstream signaling event responsible for the antiapoptotic 
effect of Bcr-Abl is not capable of enduring for that long in the absence of Bcr-Abl kinase activity.

Recently, it was shown that apoptosis mediated by STI571 is correlated with inhibition of Stat5 activity and further downregulation of $\mathrm{Bcl}-\mathrm{x}_{\mathrm{L}}{ }^{36}{ }^{3}$ Importantly, we have previously shown that $\mathrm{Bcl}-\mathrm{x}_{\mathrm{L}}$ is upregulated by Bcr-Abl in a variety of cell lines and account in part for the resistant phenotype observed in Bcr-Abl-positive cells. ${ }^{14}$ However, our results shown here suggest that $\mathrm{BCl}-\mathrm{x}_{\mathrm{L}}$ is not involved in the short-term resistance to apoptosis observed in the absence of Bcr-Abl tyrosinekinase, since Bcr-Abl cells maintained their resistant phenotype under conditions where STI571 induced a significant downregulation of $\mathrm{BCl}-\mathrm{x}_{\mathrm{L}}$.

Another important point to make is that perhaps some survival signals emerging from the expression of Bcr-Abl might be independent of its catalytic activity. In this regard, it was previously reported that some functions of c-Abl are independent of its tyrosine-kinase activity. ${ }^{37,38}$ Although it was not under the scope of this work, we envision the possibility that antiapoptotic signals can be triggered by the expression of a kinase-deficient Bcr-Abl molecule, provided a high level of expression can be achieved.

At a first sight, our hypothesis would contrast with the wellestablished paradigm that Bcr-Abl tyrosine-kinase activity is essential to transformation. However, we should keep in mind that even though low levels of Bcr-Abl are enough to provide growth factor independence, only high levels of Bcr-Abl support additional protection against apoptogenic stimuli. ${ }^{39}$ Therefore, there must be qualitative differences between signals that provide transformation (growth factor and/or anchorage independence) and resistance to apoptosis. In fact, these same authors showed that addition of growth factors to low Bcr-Abl-expressing cells did not afford the same degree of resistance to apoptosis as high levels of BcrAbl. ${ }^{39}$

Our data presented here clearly show that (a) pY-containing proteins does not directly participate in the resistance to apoptosis in Bcr-Abl-positive cells and (b) pharmacological inhibition of Bcr-Abl tyrosine-kinase, even by the specific inhibitor STI571, does not alter the resistance to apoptosis in a short term, providing the rationale and the model for investigating secondary antiapoptotic signals that might contribute to the resistance to chemotherapy found in $\mathrm{Ph}$ chromosome-positive leukemia.

\section{Materials and Methods}

\section{Cell culture}

$\mathrm{HL}-60$ and K562 cells were obtained from ATCC. LAMA84 cells were a gift from Dr. James Griffin (Dana-Farber Cancer Institute, USA), whereas KCL22 were kindly provided by Dr. Owen Witte (UCLA, USA). HL-60.Bcr$\mathrm{Abl}$ cells were derived from wild-type $\mathrm{HL}-60$ by retroviral transfection with pSR $\alpha M S V p 185^{b c r-a b}$ tkneo $^{14,40}$ and HL-60.Bcr-Abl/JW cells were derived by retroviral transfection with pSLXCMVp185 ${ }^{\text {bcr-c-abl }}$ (which has a human $\mathrm{Bcr} /$ mouse c-Abl fusion protein, provided by Dr. Jean Wang, UCSD, USA). Cells were routinely cultured in RPMI-1640 supplemented with $10 \%$ fetal calf serum (FCS), $25 \mathrm{~mm}$ Hepes, $2 \mathrm{mM} \mathrm{L-glutamine,} 100 \mathrm{U} / \mathrm{ml}$ penicillin and $100 \mu \mathrm{g} / \mathrm{ml}$ streptomycin.

\section{Antibodies and reagents}

Etoposide (VP 16), teniposide (VM 26) and staurosporine (STS) were prepared as 100, 10 and $1 \mathrm{~mm}$ solutions in dimethyl sulfoxide (DMSO), respectively. Cycloheximide (CHX) was prepared in ethanol as $50 \mathrm{~mm}$ solution. Genistein and herbimycin A were prepared in DMSO at 25 and $0.5 \mathrm{mg} / \mathrm{ml}$, respectively. STI571 was generously provided by Dr. Anna Maria Suter (Novartis Pharma AG, Switzerland), and prepared as $10 \mathrm{~mm}$ stock solution in DMSO. Annexin-V-FITC was obtained from BioWhittaker, Inc. (Walkersville, MD, USA).

Antibodies were obtained from different sources. Anti-caspase-3, antiPARP, anti-Bcl-2, anti-Bcl- $\mathrm{x}_{\mathrm{L}}$ Polyclonal antibodies (pAbs) (Pharmingen, San Diego, CA, USA), anti-pY monoclonal antibody (mAb) (Upstate Biotech Inc., Lake Placid, NY, USA), anti-c-Abl mAb (Calbiochem, San Diego, CA, USA), anti-fodrin mAb (Chemicon International), anti-actin mAb (ICN, Costa Mesa, CA, USA), anti-mouse IgG-HRP and anti-rabbit Ig-HRP (Amersham Pharmacia Biotech, Uppsala, Sweden) were used as suggested by the manufacturers.

\section{Analysis of DNA content by flow cytometry}

DNA fragmentation as an indicative of apoptosis was evaluated according to Nicoletti et al. ${ }^{41}$ Briefly, 2-3 $\times 10^{5}$ cells were harvested, washed in PBS and resuspended in $300 \mu \mathrm{l}$ of a hypotonic fluorochrome solution (HFS, $50 \mu \mathrm{g} / \mathrm{ml}$ propidium iodide in $0.1 \%$ sodium citrate plus $0.1 \%$ Triton $\mathrm{X}-100$ ). The fluorescence of individual nuclei was measured using a FACScalibur flow cytometer (Becton-Dickinson, Mountain View, CA, USA). The results represent the average percentage of hypodiploid nuclei in triplicate samples. The variations among the triplicates were always less than $10 \%$. Every experiment was repeated at least three times.

\section{Annexin V staining of apoptotic cells}

The translocation of phosphatidylserine (PS) residues from the inner to the outer leaflet of plasma membrane, as an early indicative of apoptosis, ${ }^{42,43}$ was assessed by reaction with Annexin V - FITC and scored in a FACScalibur flow cytometer (Becton-Dickinson, Mountain View, CA, USA).

\section{Western-blot analysis}

Cells were harvested, washed once in ice-cold PBS, lysed directly in SDSsample buffer (50 mM Tris- $\mathrm{HCl}$, pH 6.8, 2\% SDS, 10\% glycerol, 2.5\% 2$\mathrm{ME})$ and boiled for $5 \mathrm{~min}$. Samples were resolved under reducing conditions for $2 \mathrm{~h}$ at $80 \mathrm{~V}$ in SDS-polyacrylamide gels. Separated proteins were then blotted onto polyvinylidene difluoride membranes at $80 \mathrm{~mA}$ overnight. Blots were blocked for $2 \mathrm{~h}$ in TBST (10 mM Tris-HCl, $\mathrm{pH} 7.4$, $150 \mathrm{~mm} \mathrm{NaCl}, 0.05 \%$ Tween) containing $0.1 \%$ sodium azide and $5 \%$ nonfat dried milk or $5 \%$ bovine serum albumin (BSA) and then probed for $2 \mathrm{~h}$ with an appropriate dilution of the primary antibody. Reactions were detected with suitable secondary antibody conjugated to horseradish peroxidase (Jackson Laboratory, Bar Harbor, ME, USA and Amersham, Arlington, IL, USA) using enhanced chemiluminescence (Pierce, Rockford, IL, USA).

\section{Acknowledgements}

We thank Dr. Owen Witte and James Griffin for kindly providing the KCL22 and LAMA84 cells, respectively. We also thank Dr. Anna Maria Suter (Novartis Pharma AG, Switzerland) for the generous gift of the STI571. We 
are indebted to Dr. Seamus Martin for helpful discussion. AEBBS was a recipient of an undergraduate program award from the Conselho Nacional de Desenvolvimento Científico e Tecnológico (CNPq-Brazil) and is now under support of a MSc fellowship from Fundação de Amparo à Pesquisa do Estado de São Paulo (FAPESP-Brazil). G.B. was a recipient of a MSc fellowship from FAPESP. This work was supported by NIH Grants CA69381 and Al47891 to DRG and by grants from FAPESP and CNPq to GPAM.

\section{References}

1. Kerr JF, Wyllie AH and Currie AR (1972) Apoptosis: a basic biological phenomenon with wide-ranging implications in tissue kinetics. Br. J. Cancer 26: 239-257

2. Bresciani F, Paoluzi R, Benassi M, Nervi C, Casale C and Ziparo E (1974) Cell kinetics and growth of squamous cell carcinomas in man. Cancer Res. 34: 2405-2415

3. Mauro MJ and Druker BJ (2001) Chronic myelogenous leukemia. Curr. Opin Oncol. 13: 3-7

4. Pane F, Frigeri F, Sindona M, Luciano L, Ferrara F, Cimino R, Meloni G, Saglio G, Salvatore F and Rotoli B (1996) Neutrophilic-chronic myeloid leukemia: a distinct disease with a specific molecular marker (BCR/ABL with C3/A2 junction). Blood 88: 2410-2414

5. Cortez D, Kadlec L and Pendergast AM (1995) Structural and signaling requirements for $\mathrm{BCR}-\mathrm{ABL}-$ mediated transformation and inhibition of apoptosis. Mol. Cell. Biol. 15: 5531-5541

6. McGahon A, Bissonnette R, Schmitt M, Cotter KM, Green DR and Cotter TG (1994) BCR-ABL maintains resistance of chronic myelogenous leukemia cells to apoptotic cell death. Blood 83: 1179-1187

7. McLaughlin J, Chianese E and Witte ON (1989) Alternative forms of the BCR$\mathrm{ABL}$ oncogene have quantitatively different potencies for stimulation of immature lymphoid cells. Mol. Cell. Biol. 9: 1866-1874

8. Lugo TG, Pendergast AM, Muller AJ and Witte ON (1990) Tyrosine kinase activity and transformation potency of bcr-abl oncogene products. Science 247: 1079-1082

9. Afar DE, Goga A, McLaughlin J, Witte ON and Sawyers CL (1994) Differential complementation of Bcr-Abl point mutants with c-Myc. Science 264: 424-426

10. Goga A, McLaughlin J, Afar DE, Saffran DC and Witte ON (1995) Alternative signals to RAS for hematopoietic transformation by the BCR-ABL oncogene. Cell 82: 981-988

11. McWhirter JR and Wang JY (1993) An actin-binding function contributes to transformation by the Bcr-Abl oncoprotein of Philadelphia chromosomepositive human leukemias. EMBO J. 12: 1533-1546

12. McWhirter JR, Galasso DL and Wang JY (1993) A coiled-coil oligomerization domain of Bcr is essential for the transforming function of Bcr-Abl oncoproteins. Mol. Cell. Biol. 13: 7587-7595

13. Pendergast AM, Quilliam LA, Cripe LD, Bassing CH, Dai Z, Li N, Batzer A, Rabun KM, Der CJ and Schlessinger J et al. (1993) BCR-ABL-induced oncogenesis is mediated by direct interaction with the $\mathrm{SH} 2$ domain of the GRB2 adaptor protein. Cell 75: 175-185

14. Amarante-Mendes GP, McGahon AJ, Nishioka WK, Afar DE, Witte ON and Green DR (1998) Bcl-2-independent Bcr-Abl-mediated resistance to apoptosis: protection is correlated with up regulation of $\mathrm{Bcl}-\mathrm{xL}$. Oncogene 16: 1383-1390

15. Gesbert F and Griffin JD (2000) Bcr/Abl activates transcription of the $\mathrm{Bcl}-\mathrm{X}$ gene through STAT5. Blood 96: 2269-2276

16. de Groot RP, Raaijmakers JA, Lammers JW and Koenderman L (2000) STAT5dependent cyclinD1 and Bcl-xL expression in Bcr-Abl-transformed cells. Mol. Cell. Biol. Res. Commun. 3: 299-305

17. Horita M, Andreu EJ, Benito A, Arbona C, Sanz C, Benet I, Prosper F and Fernandez-Luna JL (2000) Blockade of the Bcr-Abl kinase activity induces apoptosis of chronic myelogenous leukemia cells by suppressing signal transducer and activator of transcription 5-dependent expression of $\mathrm{Bcl}-\mathrm{xL}$. J. Exp. Med. 191: 977-984

18. Tang X, Downes CP, Whetton $A D$ and Owen-Lynch PJ (2000) Role of phosphatidylinositol 3-kinase and specific protein kinase $B$ isoforms in the suppression of apoptosis mediated by the Abelson protein-tyrosine kinase. J. Biol. Chem. 275: 13142-13148
19. Skorski T, Bellacosa A, Nieborowska-Skorska M, Majewski M, Martinez R, Choi JK, Trotta R, Wlodarski P, Perrotti D, Chan TO, Wasik MA, Tsichlis PN and Calabretta B (1997) Transformation of hematopoietic cells by BCR/ABL requires activation of a PI-3k/Akt-dependent pathway. EMBO J. 16: 6151-6161

20. Amarante-Mendes GP, Jascur T, Nishioka WK, Mustelin T and Green DR (1997) Bcr-Abl-mediated resistance to apoptosis is independent of PI 3-kinase activity. Cell Death Diff. 4: 548-554

21. Wang CY, Mayo MW, Korneluk RG, Goeddel DV and Baldwin Jr AS (1998) NFkappaB antiapoptosis: induction of TRAF1 and TRAF2 and c-IAP1 and c-IAP2 to suppress caspase-8 activation. Science 281: 1680-1683

22. Hamdane M, David-Cordonnier MH and D'Halluin JC (1997) Activation of p65 $N F-\kappa B$ protein by $210 B C R-A B L$ in a myeloid cell line (P210BCR-ABL activates p65 NF- $\kappa$ B). Oncogene 15: 2267-2275

23. Reuther JY, Reuther GW, Cortez D, Pendergast AM and Baldwin Jr AS (1998) A requirement for NF- $\kappa$ B activation in Bcr-Abl-mediated transformation. Genes Dev. 12: 968-981

24. Mauro MJ and Druker BJ (2001) STI571: targeting BCR-ABL as therapy for CML. Oncologist 6: 233-238

25. Deininger MW, Goldman JM, Lydon N and Melo JV (1997) The tyrosine kinase inhibitor CGP57148B selectively inhibits the growth of BCR-ABL-positive cells. Blood 90: 3691-3698

26. Druker BJ, Tamura S, Buchdunger E, Ohno S, Segal GM, Fanning S, Zimmermann $\mathrm{J}$ and Lydon NB (1996) Effects of a selective inhibitor of the Abl tyrosine kinase on the growth of Bcr-Abl positive cells. Nat. Med. 2: 561-566

27. Sawyers CL (2001) Molecular studies in chronic myeloid leukemia patients treated with tyrosine kinase inhibitors. Semin. Hematol. 38: 15-21

28. Druker BJ and Lydon NB (2000) Lessons learned from the development of an Abl tyrosine kinase inhibitor for chronic myelogenous leukemia. J. Clin. Invest. 105: 3-7

29. Druker BJ, Sawyers CL, Kantarjian H, Resta DJ, Reese SF, Ford JM, Capdeville R and Talpaz M (2001) Activity of a specific inhibitor of the BCR-ABL tyrosine kinase in the blast crisis of chronic myeloid leukemia and acute lymphoblastic leukemia with the Philadelphia chromosome. N. Engl. J. Med. 344: 1038-1042

30. Weisberg E and Griffin JD (2000) Mechanism of resistance to the ABL tyrosine kinase inhibitor STI571 in BCR/ABL-transformed hematopoietic cell lines. Blood 95: 3498-3505

31. Mahon FX, Deininger MW, Schultheis B, Chabrol J, Reiffers J, Goldman JM and Melo JV (2000) Selection and characterization of BCR-ABL positive cell lines with differential sensitivity to the tyrosine kinase inhibitor STI571: diverse mechanisms of resistance. Blood 96: 1070-1079

32. le Coutre P, Tassi E, Varella-Garcia M, Barni R, Mologni L, Cabrita G, Marchesi E, Supino R and Gambacorti-Passerini C (2000) Induction of resistance to the Abelson inhibitor STI571 in human leukemic cells through gene amplification. Blood 95: 1758-1766

33. Gorre ME, Mohammed M, Ellwood K, Hsu N, Paquette R, Rao PN and Sawyers CL (2001) Clinical resistance to STI-571 cancer therapy caused by BCR-ABL gene mutation or amplification. Science 293: 876-880

34. le Coutre P, Mologni L, Cleris L, Marchesi E, Buchdunger E, Giardini R, Formelli $F$ and Gambacorti-Passerini C (1999) In vivo eradication of human BCR/ABLpositive leukemia cells with an ABL kinase inhibitor. J. Natl. Cancer Inst. 91: 163-168

35. Fang G, Kim CN, Perkins CL, Ramadevi N, Winton E, Wittmann S and Bhalla KN (2000) CGP57148B (STI-571) induces differentiation and apoptosis and sensitizes Bcr-Abl-positive human leukemia cells to apoptosis due to antileukemic drugs. Blood 96: 2246-2253

36. Donato NJ, Wu JY, Zhang L, Kantarjian H and Talpaz M (2001) Downregulation of interleukin-3/granulocyte-macrophage colony-stimulating factor receptor $\beta$-chain in BCR-ABL(+) human leukemic cells: association with loss of cytokine-mediated Stat-5 activation and protection from apoptosis after BCRABL inhibition. Blood 97: 2846-2853

37. Welch PJ and Wang JY (1995) Abrogation of retinoblastoma protein function by $\mathrm{c}-\mathrm{Abl}$ through tyrosine kinase-dependent and -independent mechanisms. Mol. Cell. Biol. 15: 5542-5551

38. Henkemeyer M, West SR, Gertler FB and Hoffmann FM (1990) A novel tyrosine kinase-independent function of Drosophila $\mathrm{Abl}$ correlates with proper subcellular localization. Cell 63: 949-960

39. Cambier N, Chopra R, Strasser A, Metcalf D and Elefanty AG (1998) BCR-ABL activates pathways mediating cytokine independence and protection against 
apoptosis in murine hematopoietic cells in a dose-dependent manner. Oncogene 16: 335-348

40. Amarante-Mendes GP, Naekyung Kim C, Liu L, Huang Y, Perkins CL, Green DR and Bhalla K (1998) Bcr-Abl exerts its antiapoptotic effect against diverse apoptotic stimuli through blockage of mitochondrial release of cytochrome $c$ and activation of caspase-3. Blood 91: 1700-1705

41. Nicoletti I, Migliorati G, Pagliacci MC, Grignani F and Riccardi C (1991) A rapid and simple method for measuring thymocyte apoptosis by propidium iodide staining and flow cytometry. J. Immunol. Methods 139: 271-279
42. Martin SJ, Finucane DM, Amarante-Mendes GP, O'Brien GA and Green DR (1996) Phosphatidylserine externalization during CD95-induced apoptosis of cells and cytoplasts requires ICE/CED-3 protease activity. J. Biol. Chem. 271: 28753-28756

43. Martin SJ, Reutelingsperger CPM, McGahon AJ, Rader J, van Schie RCAA, LaFace DM and Green DR (1995) Early redistribution of plasma membrane phosphatidylserine is a general feature of apoptosis regardless of the initiating stimulus: inhibition by overexpression of Bcl-2 and Abl. J. Exp. Med. 182: $1-12$ 